\title{
Author Correction: Superconductivity mediated by polar modes in ferroelectric metals
}

\author{
C. Enderlein, J. Ferreira de Oliveira, D. A. Tompsett, E. Baggio Saitovitch, S. S. Saxena (D, G. G. Lonzarich \& \\ S. E. Rowley (D)
}

Correction to: Nature Communications https:/doi.org/10.1038/s41467-020-18438-0, published online 25 September 2020.

The original version of this Article contained an error in the caption of Fig. 1, which incorrectly says " $\mathrm{SrTi}\left({ }^{16} \mathrm{O}_{1-y}{ }^{18} \mathrm{O}_{y}\right) 3$ ", but in fact it should read " $\operatorname{SrTi}\left({ }^{16} \mathrm{O}_{1-x}{ }^{18} \mathrm{O}_{x}\right)_{3}$ ".

Published online: 15 October 2020 \begin{abstract}
reproduction in any medium or format, as long as you give appropriate credit to the original author(s) and the source, provide a link to the Creative Commons license, and indicate if changes were made. The images or other third party material in this article are included in the article's Creative Commons license, unless indicated otherwise in a credit

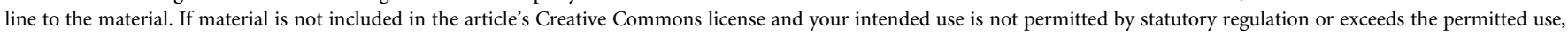
you will need to obtain permission directly from the copyright holder. To view a copy of this license, visit http://creativecommons.org/licenses/by/4.0/.
\end{abstract}

c) Open Access This article is licensed under a Creative Commons Attribution 4.0 International License, which permits use, sharing, adaptation, distribution and

(C) The Author(s) 2020 